\title{
SEROPREVALENCE AND SPREADING OF BRUCELLA OVIS IN SOUTH BAČKA AND SREM DISTRICT
}

\author{
Sara Savić1 ${ }^{*}$, Marina Žekić Stošić ${ }^{1}$, Ivan Pušić ${ }^{1}$, Vladimir Polaček ${ }^{1}$, \\ Živoslav Grgić ${ }^{1}$, Doroteja Marčić ${ }^{1}$, Miroljub Dačić ${ }^{2}$, Dejan Bugarski ${ }^{1}$ \\ ${ }^{1}$ Scientific Veterinary Institute "Novi Sad", Novi Sad, Serbia \\ ${ }^{2}$ Veterinary Specialist Institute Jagodina, Jagodina, Serbia
}

\begin{abstract}
Ovine brucellosis can cause epididymitis and reduce fertility in rams and therefore is an important disease in sheep and rams from economic point of view. Sometimes it causes abortions and increased perinatal mortality in sheep as well, but it primarily affects male animals. Brucella ovis was first identified in northern region of Serbia, in 2008-2009 during a research study. Specific antibodies against Brucella ovis were detected in the sheep that originated from Becej and Titel municipalities in the South Bačka district. The prevalence was low, only $0.89 \%$. For the purpose of this study, a total number of 6,407 serum samples from rams and sheep were used. All of the samples were from the northern part of Serbia, belonging to South Bačka and Srem districts. Serological test was performed in order to determine the presence of specific antibodies against Brucella ovis in rams and sheep, by ELISA test (indirect ELISA - iELISA). The prevalence varied from $0 \%-19.3 \%$ during the years. If we look into the municipalities of South Bačka and Srem district, we can see that the numbers of positive samples are different, and the number of analyzed samples varies. The overall seroprevalence from 2014-2018 in South Bačka and Srem district is 6.15\%, but it varies significantly among different municipalities from 0 to $26 \%$. The majority of analyzed sample were from rams and all of the positive findings are in rams. Only a small number of sheep (female) has been examined so far, so the prevalence among females is still unknown.
\end{abstract}

Key words: Brucella ovis, epididimidis, seroprevalence

1*Corresponding author: sara@niv.ns.ac.rs 


\title{
SEROPREVALENCA I ŠIRENJE BRUCELLA OVIS U JUŽNOBAČKOM I SREMSKOM OKRUGU
}

\author{
Sara Savićn ${ }^{1}$, Marina Žekić Stošić ${ }^{1}$, Ivan Pušić ${ }^{1}$, Vladimir Polaček ${ }^{1}$,

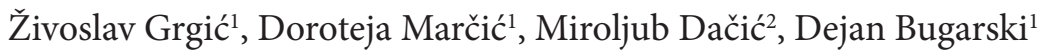 \\ ${ }^{1}$ Naučni institut za veterinarstvo "Novi Sad", Novi Sad \\ ${ }^{2}$ Veterinarski specijalistički institut Jagodina, Jagodina
}

\section{Kratak sadržaj}

Bruceloza ovaca može izazvati epididimitis i smanjenu plodnost kod ovnova zbog toga je ova bolest važna sa ekonomskog gledišta kod gajenja ovaca. Ponekad može da izazove i perinatalna uginuća kod ovaca, ali je primarni efekat oboljenja ipak na ovnovima. U severnom delu Srbije, Brucella ovis je po prvi put identifikovana u periodu 2008-2009, tokom naučnog istraživanja. Specifična antitela protiv Brucella ovis su utvrđena kod životinja koje potiču iz opština Bečej i Titel, u Južnobačkom okrugu. Prevalenca je bila niska, 0.89\%. Za potrebe ovog istraživanja pregledano je ukupno 6.407 seruma ovnova i ovaca. Svi uzorci su poticali iz severnog dela Srbije, odnosno iz Južnobačkog i Sremskog okruga. Serološki testovi su odrađeni sa ciljem da se odredi prisustvo specifičnih antitela protiv Brucella ovis u krvnim serumima ovaca i ovnova, ELISA testom (indirektna ELISA). Svi uzorci potiču sa područja Južnobačkog u Sremskog okruga. Tokom perioda od 5 godina, seroprevalenca je varirala od $0 \%$ - 19.3\%. Ako se pogleda pojedinačno po opštinama u Južnobačkom i Sremskom okrugu, može se videti razlika u broju pozitivnih nalaza, ali i razlika u broju ispitanih uzoraka. Ukupna seroprevalenca za Južnobački i Sremski okrug tokom perioda 2014-2018 godine je $6.15 \%$, ali su značajne razlike u seroprevalenci između različitih opština, od 0 do $26 \%$. Najveći broj uzoraka je poticao od priplodnih ovnova, pa i pozitivni nalazi potiču od ovnova. Samo mali broj uzoraka je poticao od ovaca do sada, tako da je seroprevalenca među ovcama još uvek nepoznata.

Ključne reči: Brucella ovis, epididimidis, seroprevalenca

\section{INTRODUCTION}

Ovine brucellosis (epididymitis) can cause epididymitis and reduced fertility in rams and therefore is an important disease in sheep and rams from economic point of view. Sometimes it causes abortions and increased perinatal mortality as well, but it primarily affects male animals. The infection causes severe inflamma- 
tion of the epididymis in rams, which can later lead to formation of spermatocoeles and fibrinous adhesions. The disease is notifiable to the World Organization for Animal Health (OIE) and it is known to be present worldwide. Unlike most species of Brucella, Brucella ovis does not seem to infect humans (OIE, 2018)

\section{Etiology}

Causative agent of brucellosis in sheep is Brucella ovis (B. ovis). B. ovis is a Gram-negative bacteria from the family Brucellaceae. The causative agent is a gram-negative coccobacillus or short rod, facultative intracellular pathogen. Rams often become persistently infected with B. ovis, and many animals can shed the bacteria in semen for 2-4 years or longer. Shedding can occur with or without clinical signs, and it can be intermittent. Rams can also excrete this organism in urine. Ewes are relatively resistant to infection, and if they become infected, the organism clears the bacteria in a short time. In ewes the organism is shed in vaginal discharges and milk. The infection seems to be transient and rarely spans more than one pregnancy. If mothers are infected, lambs could be infected by nursing, but congenital infection seems to be rare. B. ovis can be transmitted from ram to ram via ewes, which in that case act as mechanical vectors. Some of those ewes do not even become infected. Such ewes have been reported to carry this organism in the vagina for at least 2 months. Ram-to-ram transmission is very rare. Some experiments indicate that this organism can enter the body via the prepuce, conjunctiva, and oral, nasal and rectal mucosae, which would mean a possibility of infection by preputial licking or other forms of oral transmission, and transmission when rams mount each other. Despite all the possibilities, the passive genital transmission is a common method of infection.

Contamination of pastures does not seem to be an important method of transmission. Sheep did not become infected when they grazed fields that had recently been occupied by infected animals, or when they were kept in enclosures next to infected animals. Rams are more susceptible than sheep, and the disease affects adult animals (Burgess, 1982).

In the northern region of Serbia, B. ovis was identified in 2008-2009 for the first time during a study done on 1,500 sera samples from sheep and rams examined by the method of complement fixation. In that study the findings of specific antibodies against $B$. ovis in dilution 1:5 were considered positive. Specific antibodies against $B$. ovis were detected in the sheep that originated from Becej and Titel municipalities in South Bačka district. The prevalence was low, only $0.89 \%$. In Central Banat district, where only rams were examined, the seroprevalence for B. ovis was higher with $4.29 \%$ of positive findings, while in Srem district there 
were no animals seropositive to B. ovis (Grgić et al., 2009), the trade or exchange of rams between herds is common In Serbia. Therefore, this is one of the reasons for the spreading of this contagious diseases to among the herds, especially since a considerable number of breeders does not comply with the recommendations for health check of rams. At approximately the same time, Brucella ovis was found in neighboring country of Croatia (Špičić et al., 2009).

Another research was carried out in 2011 in the northern region of Serbia. The total of 88 rams originating from 32 herds in 19 settlements were examined. The average age of animals was $3.1 \pm 1.43$ year. The examined rams were of different breeds: Merinolanscaf, Ile-de-France, Suffolk breed, Tsigai, Charollais and crossbreeds. In this study the diagnostic method performed was ELISA for examining the rams to Brucella ovis (ram epididymitis). The percentage of seropositive rams for B. ovis was 3.41\% (Bugarski et al., 2011). Later on, in another study, it was reported that B. ovis was found in rams, in the south part of Serbia, in Pirot municipality (Petrović et al., 2014).

\section{Clinical Signs}

Brucellosis caused by B. ovis in rams can cause epididymitis, orchitis and reduced fertility. Epididymitis manifests as an enlargement of the epididymis, especially the tail and pain or discomfort in animals on palpation. Palpable lesions can be found in the epididymis and scrotum in $30-50 \%$ of animals. The lesions can be unilateral or bilateral, although unilateral lesions are reported to be more common. Nodules or other abnormalities may also be detected, and testicles sometimes shrink in chronic cases. Palpable lesions are permanent in most rams (Arsenault et al., 2004).

In most cases poor quality semen with increased number of white blood cells may be the only sign of infection. Sperm motility and concentration may be decreased, and individual sperm is often abnormal. In ewes B. ovis can cause abortions, stillbirths and increased perinatal mortality and birth of weak or small lambs in some ewes, but such reproductive loses are rarely reported in the field. Systemic clinical symptoms are rare in adult ewes and rams. In the 2008-2009 study, in northern region of Serbia, the rams that had symptoms that could be indicating $B$. ovis infection did not have positive results in their blood samples by complement fixation method (Grgić et al., 2009).

\section{Diagnostics}

Diagnosis based on clinical symptoms is usually not enough, so the sam- 
ples of blood, semen, vaginal swab, milk and the smears of susceptible tissues should be submitted to the laboratory for cultivation of B. ovis. According to the OIE Manual of diagnostic tests and vaccines, for detection of infectious agent, staining methods, culturing and PCR can be used (OIE, 2018). The best samples for identification of B. ovis are semen, vaginal swabs and milk. On nutritive agar B. ovis may be isolated from semen samples in rams, vaginal swabs and milk in ewes, and fetal placenta after the abortion. Serological tests that can be used for diagnostic purposes are several: ELISA, agar gel immunodiffusion (AGID) and complement fixation and are usually used to detect specific antibodies to B. ovis in animals (Webb et al., 1980). The most efficient tests and widely used ones are the complement fixation test (CFT), the double agar gel immunodiffusion (AGID) test and the indirect Enzyme-Linked Immunosorbent Assay (I-ELISA) (Picard-Hagen et al., 2015). Rams with ambiguous tests should be isolated and retested after 2-4 weeks. Definitive diagnosis requires molecular diagnostic procedures as detection of nucleic acids by PCR (polymerase chain reaction) technique (Costa et al., 2013; OIE, 2018).

The only test that has been prescribed to date by the OIE and the European Union (EU) for international trade was the CFT, but different countries have adopted various standard diagnostic techniques for B. ovis. Different independent studies have shown that the ELISA is more sensitive than CFT or AGID test. AGID test and I-ELISA have been reported as more sensitive than the CFT. Also, ELISA was sometimes reported as a less specific method, but this greatly depends on the protocol used (Estein et al., 2002; Nielsen et al., 2004; Praud et al., 2012). There are several commercial ELISA diagnostic kits on the market now, all with same principle of use.

\section{MATERIAL AND METHODS}

\section{Samples}

A total number of 6,407 serum samples from rams and sheep were used in the study. All of the samples were from the Northern part of Serbia, belonging to South Bačka and Srem districts - the same region where the studies from 2009 and 2011 were performed. The sample collection was done during the annual national surveillance and monitoring program of the country, and it was repeated in the same way every year during the period of 5 years (2014-2018). All the rams with positive to $B$. ovis antibodies were sampled again and the analysis was repeated. 


\section{Detection of specific antibodies against B. ovis}

Serological test was done in order to detect the presence of specific serum antibodies against $B$. ovis in rams and sheep, by commercial indirect ELISA (iELISA, Ingezim Brucella ovis, Ingenasa, Spain), according to manufacturer's instructions. All the rams that were positive to B. ovis antibodies were sampled again and the analysis was repeated. The detection of specific antibodies to Brucella ovis in ram and sheep serum samples is based on indirect immunoenzymatic assay technique, which uses a monoclonal antibody (MAb) specific for ruminant's IgG immunoglobulins. The result of each control and sample test was expressed as a percentage (positivity (\%)), based on sample optical density (OD) reading and calculated and interpreted according to the instructions of the kit manufacturer.

\section{RESULTS AND DISCUSSION}

During the period of 5 years (2014-2018), a total number of 6,407 samples were analyzed for the presence of specific antibodies against $B$. ovis. All the samples were collected in the same region - South Bačka and Srem district, during the obligatory annual surveillance program organized by the Veterinary Directorate of the Ministry of Agriculture, Forestry and Water management.

The positive samples were found in percentage from $0 \%-19.3 \%$. The annual surveillance program of Serbia started in 2016 and therefore the number of samples has tripled compared to the previous period and continuously has been rising during the following years (Table 1).

Table 1. The number and percentage of examined and positive animals to Brucella ovis, during the period from 2014-2018.

\begin{tabular}{|cccccc|}
\hline $\begin{array}{c}\text { Year of ex- } \\
\text { amination }\end{array}$ & $\begin{array}{c}\text { Total } \\
\text { number } \\
\text { of sera }\end{array}$ & $\begin{array}{c}\text { No of } \\
\text { sera with } \\
\text { positive } \\
\text { findings }\end{array}$ & $\begin{array}{c}\text { \% of sera } \\
\text { with posi- } \\
\text { tive find- } \\
\text { ings }\end{array}$ & $\begin{array}{c}\text { No of } \\
\text { sera with } \\
\text { negative } \\
\text { findings }\end{array}$ & $\begin{array}{c}\text { \% of } \\
\text { sera with } \\
\text { negative } \\
\text { findings }\end{array}$ \\
\hline 2014 & 433 & 0 & $0 \%$ & 433 & $100 \%$ \\
\hline 2015 & 442 & 85 & $19.3 \%$ & 357 & $80.7 \%$ \\
\hline 2016 & 1,346 & 102 & $7.58 \%$ & 1242 & $92.27 \%$ \\
\hline 2017 & 1,784 & 99 & $5.55 \%$ & 1667 & $93.44 \%$ \\
\hline 2018 & 2,401 & 107 & $4.46 \%$ & 2278 & $94.87 \%$ \\
\hline Total & 6407 & 394 & & & \\
\hline
\end{tabular}


In 2014, no specific antibodies against B. ovis were found in South Bačka and Srem district. In 2015, positive samples were found and the prevalence was quite high (19.3\%) due to the fact that almost all of the samples were collected from that region of Bečej municipality and its surrounding. The aim of the sampling was to find the positive animals and not the monitoring. The majority of the positive samples came from Bečej municipality (Figure 1), the same one where positive animals were found in 2009 (Grgić et al., 2009). Two more positive animals were found in other municipalities - Srbobran, a neighboring municipality to Bečej and Bačka Palanka, further away.

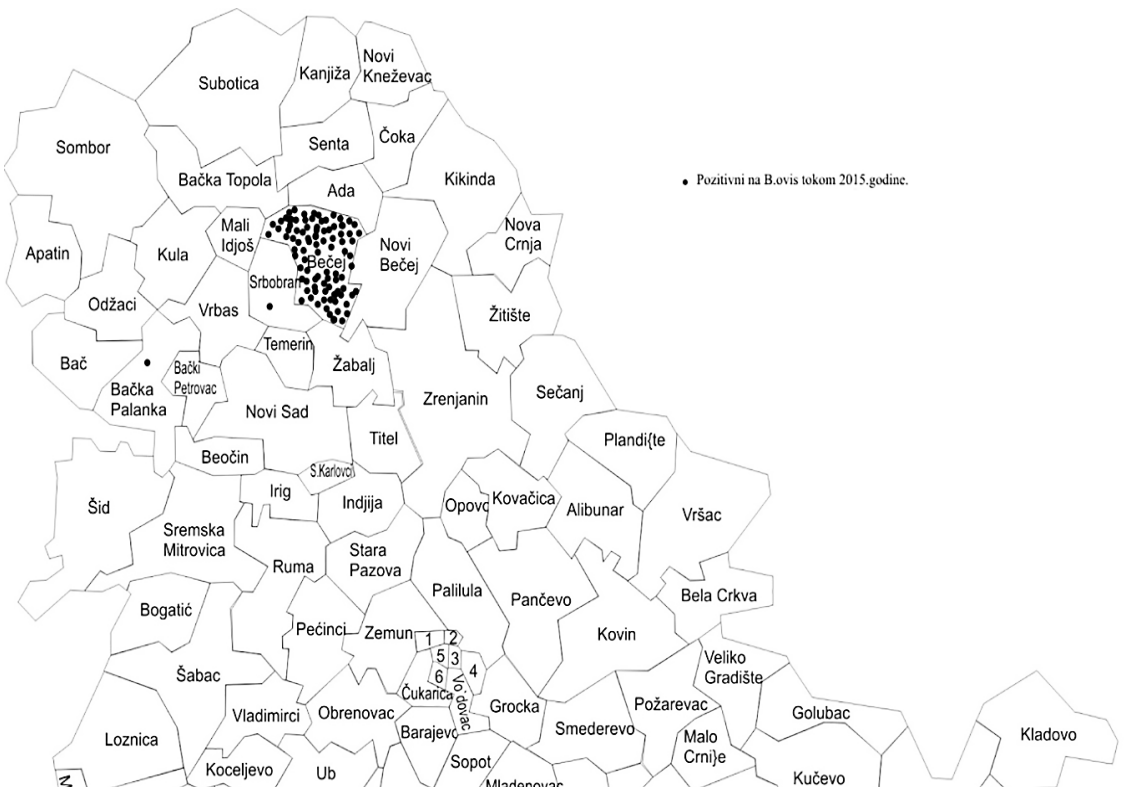

Figure 1. Location of positive animals to Brucella ovis found in 2015.

In 2016, there were far more samples examined in total and specific antibodies were found in rams and sheep originating from the following municipalities: Bečej with the highest number of positive samples followed by Žabalj and Titel. Novi Sad and Šid had a few positive findings while there were just one or two positive findings in Ruma, Pećinci, Inđija, Sremska Mitrovica, Srbobran, Bačka Palanka and Plandište (Figure 2). Seroprevalence was lower, due to a large number of samples analyzed, but it was still a higher percentage (7.58\%) than in the previous period (2009-2014). 


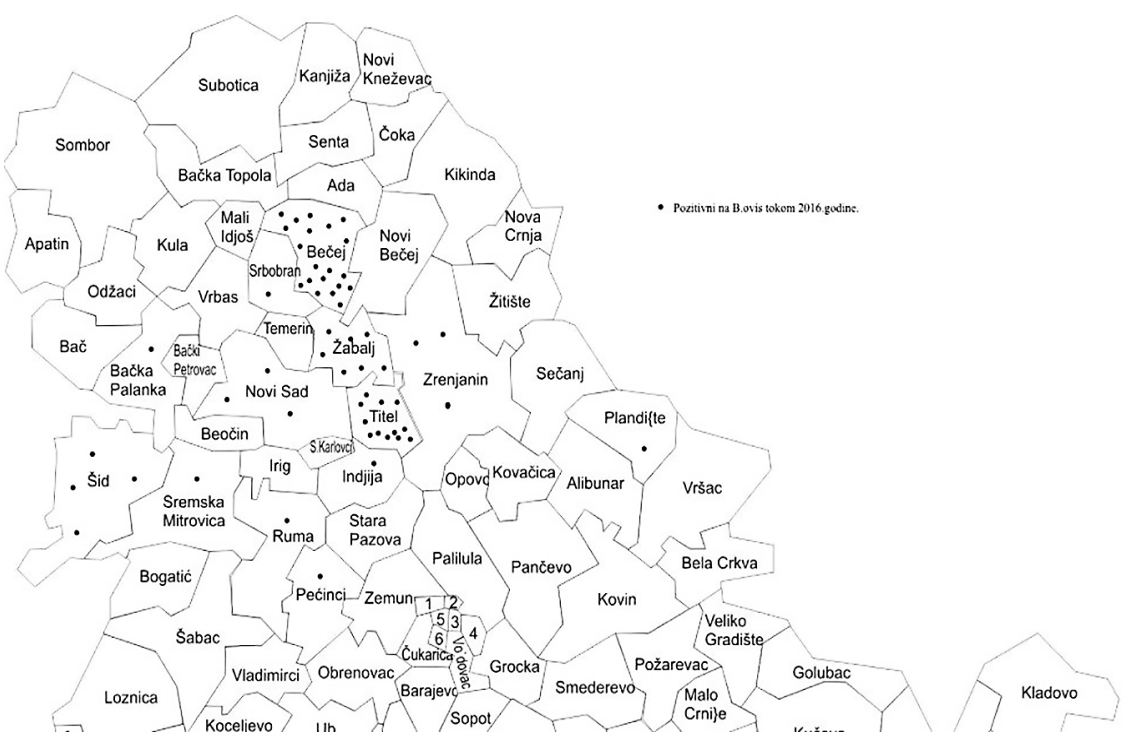

Figure 2. Location of positive animals to Brucella ovis found in 2016.

In 2017, there were again more samples analyzed then during the previous year, but the percentage of positive animals for B. ovis was similar to the previous year $(5.55 \%)$. The municipalities where they occurred, however, were different from 2016, meaning there were more municipalities where positive animals were found. The highest number of positive animals were found in the following municipalities: Bečej, Žabalj, Titel, Bačka Palanka, with just a fewer positive findings were Srbobran and Novi Sad followed by Ruma, Pećinci, Inđija, Sremska Mitrovica, Stara Pazova, Temerin and Bač (Figure 3). This indicates that the disease is now found in a broader area, but in total the prevalence is about the same. It is due to the obligational annual government program that the number of examined animals and the number of municipalities has increased. 


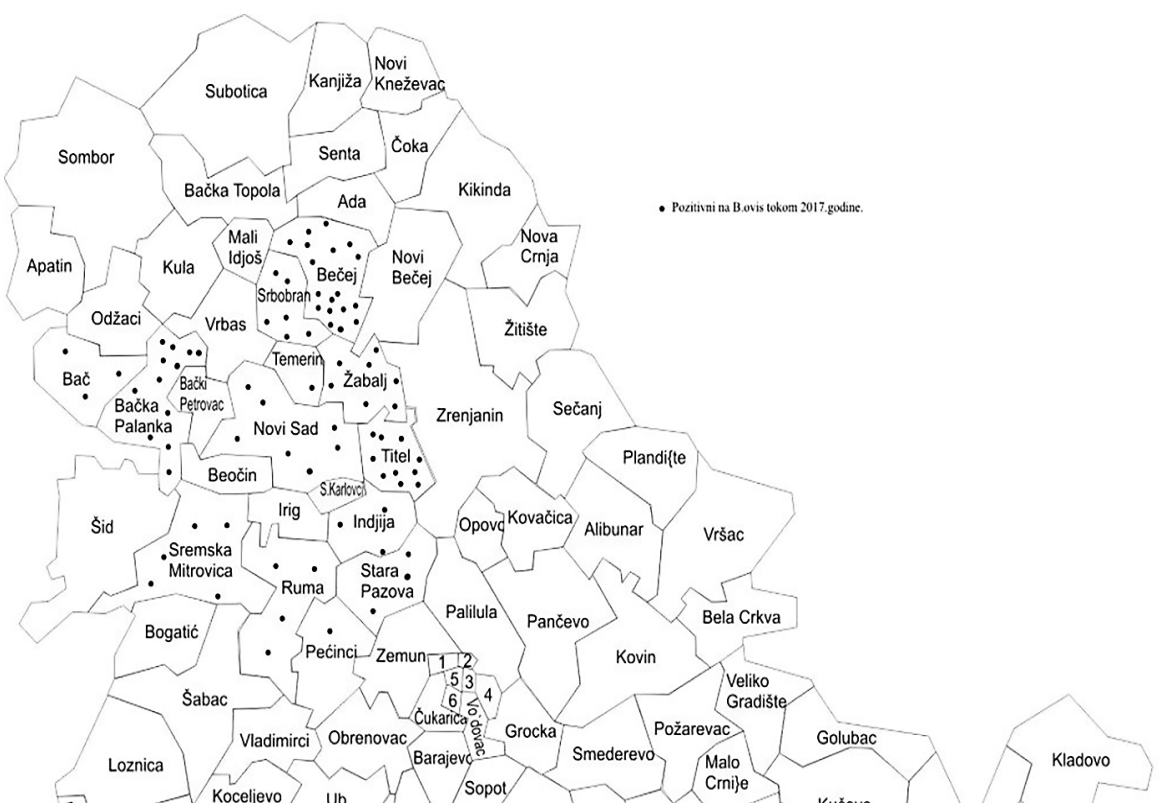

Figure 3. Location of positive animals to Brucella ovis found in 2017.

Until the end of October 2018, the total prevalence was $4.46 \%$ and the locations where the samples were collected from were pretty much the same as in 2017. With the higher number of animals examined, the total prevalence seems to be slightly dropping during that last 3 years, but the number of municipalities where the positive animals are found is rising every year. Figure 3 shows all municipalities where animals positive to $B$. ovis were found during the period from 2014-2018. 


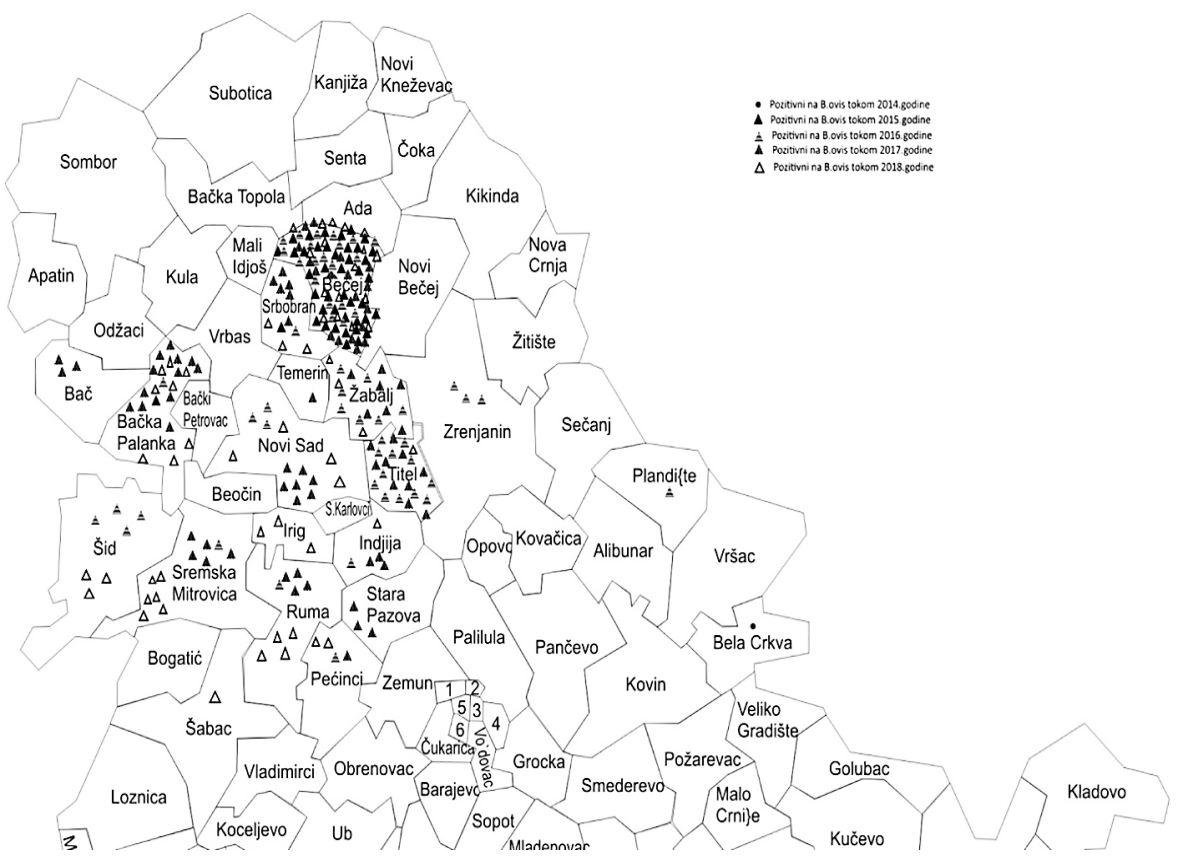

Figure 4. The locations where positive animals to Brucella ovis were found during the period 2014-2018.

If we look into the municipalities of South Bačka and Srem district, we can see that the number of positive samples is different and that the number of analyzed samples varies (Table 2). The overall seroprevalence from 2014-2018 in South Bačka and Srem district is 6.15\%, but it varies significantly among different municipalities from 0 to $26 \%$. It is also significant to point out that it is not the rule that the more samples were analyzed, the more positive ones were found. There are some municipalities with a low number of positive samples among quite a large number of tested samples that were examined (Table 2). 
Table 2. The number and percentage of examined and positive animals to Brucella ovis, during the period from 2014-2018 in different municipalities of South Bačka and Srem district.

\begin{tabular}{|lccc|}
\hline \multicolumn{1}{|c}{ Municipality } & $\begin{array}{c}\text { No of } \\
\text { analyzed } \\
\text { samples }\end{array}$ & $\begin{array}{c}\text { No of } \\
\text { positive } \\
\text { samples }\end{array}$ & $\begin{array}{c}\text { \% of } \\
\text { positive } \\
\text { samples }\end{array}$ \\
\hline Bečej & 1224 & 168 & 13.73 \\
\hline Bačka Palanka & 927 & 32 & 3.45 \\
\hline Novi Sad and Sremski Karlovci & 401 & 14 & 3.49 \\
\hline Srbobran & 365 & 10 & 2.74 \\
\hline Titel & 226 & 60 & 26.55 \\
\hline Žabalj & 311 & 27 & 8.68 \\
\hline Inđija & 182 & 6 & 3.30 \\
\hline Šid & 911 & 19 & 2.09 \\
\hline Sremska Mitrovica & 603 & 30 & 4.98 \\
\hline Pećinci & 196 & 6 & 3.06 \\
\hline Ruma & 306 & 8 & 2.61 \\
\hline Stara pazova & 131 & 4 & 3.05 \\
\hline Bač & 275 & 3 & 1.09 \\
\hline Bački Petrovac & 44 & 1 & 2.27 \\
\hline Beočin & 71 & 0 & 0.00 \\
\hline Irig & 120 & 5 & 4.17 \\
\hline Temerin & 114 & 1 & 0.88 \\
\hline TOTAL & 6407 & 394 & 6.15 \\
\hline
\end{tabular}

In conclusion, Brucella ovis in northern part of Serbia exists and is spreading around the municipality where it has been primarily found in 2009 (Grgić et al., 2009). The total prevalence seems to be slightly decreasing during the last 3 years but still not all the animals in the region have been analyzed. Also, mostly rams were analyzed and all of the positive findings are in rams. Only a small number of sheep (female) has been examined so far so the prevalence among females is rather unknown. The national annual surveillance and monitoring program is to be continued, but today it is more familiar which municipalities are with the highest prevalence for $B$. ovis. The sheep breeders must 
obey the annual national program in the attempt to stop the spreading of the infection.

\section{AKNOWLEDGEMENT}

This work was supported by a grant from scientific project TR 31071 ("Research on pharmacological characteristics of antimicrobial agents, introduction of new technological alternative methods of prophylactic with the purpose to improve control of infectious animal disease of farm animals") of Ministry of Education and Science of Republic of Serbia.

\section{REFERENCES}

1. Arsenault J., Girard C., Dubreuil P., Bélanger D.: Lack of evidence of Brucella ovis infection in rams infection in rams in Quebec. Canadian Veterinary Journal, 45, 4, 312-314. 2004.

2. Bugarski D., Savic S., Grgic Z., Vidic B., Milovanovic A., Barna T.: Seroepidemiological examination of contagious diseases in breeding rams- preliminary examinations. IN: Biljana Radojičić, and Stanko Boboš Proceedings 19th International Congress of Mediterranean Federation of Health and Production of Ruminants, May 25-28, Belgrade, Faculty of Veterinary Medicine, 2011, 107-10.

3. Burgess G.W.: Ovine contagious epididymitis: a review. Veterinary Microbiology, 7, 6, 551-575, 1982.

4. Costa L.F., Nozaki C.N., Lira N.S.C., Antunes J.M.A.P., Xavier M.N, Costa E.A., Paixão T.A., Santos R.L., Megid J.: Species-specific nested PCR as a diagnostic tool for Brucella ovis infection in rams. Arquivo Brasileiro de Medicina Veterinária e Zootecnia, 65, 1, 55-60, 2013.

5. Estein S.M., Baldi P.C., Bowden R.A.: Comparison of serological tests based on outer membrane or internal antigens for detecting antibodies to Brucella ovis in infected flocks. Journal of Veterinary Diagnostic Investigation, 14, 407-411, 2002.

6. Grgić Ž., Vidić B., Savić S., Milovanović A.: Ispitivanje prisustva infekcije sa Brucella ovis (Ovine epididymitis) kod ovaca. Arhiv veterinarske medicine, 2 (1), 17-25, 2009.

7. Nielsen K., Smith P., Conde S., Draghi de Benitez G., Gall D., Halbert G., Kenny K., Massengill C., Muenks Q., Rojas X., Perez B., Samartino L., Silva P., Tollersrud T., Jolley M.: Rough lipopolysaccharide of Brucella abortus RB51 as a common antigen for serological detection of B. ovis, B. canis, 
and B. abortus RB51 exposure using indirect enzyme immunoassay and fluorescence polarization assay. Journal of Immunoassay and Immunochemistry, 25, 171-182, 2004.

8. Petrović M., Špičić S., Potkonjak A., Lako B., Kostov M., Cvetnić Ž.: First evidence of Brucella ovis infection in rams in the Pirot Municipality, Serbia. Veterinaria italiana 50, 4, 259-68, 2014.

9. Picard-Hagen N., Berthelot X., Champion JL., Eon L., Lyazrhi F., Marois M., Peglion M., Schuster A., Trouche C., Garin-Bastuji B.: Contagious epididymitis due to Brucella ovis: relationship between sexual function, serology and bacterial shedding in semen. BMC Veterinary Research, 11, 125, 2015.

10. Praud A., Champion JL., Corde Y., Drapeau A., Meyer L., Garin-Bastuji B.: Assessment of the diagnostic sensitivity and specificity of an indirect ELISA kit for the diagnosis of Brucella ovis infection in rams. BMC Veterinary Research, 8, 68, 2012.

11. Špičić S., Marjanović S., Zdelar-Tuk M., Cvetnić Z.: First evidence of Brucella ovis infection in Republic of Croatia. Deutsche tierärztliche Wochenschrift, 116, 6, 209-13, 2009.

12. Webb R.F., Quinn C.A., Cockram F.A., Husband A.J.: Evaluation of procedures for the diagnosis of Brucella ovis infection in rams. Australian Veterinary Journal, 56, 172-175, 1980.

13. World Organization for Animal Health (OIE). Manual of diagnostic tests and vaccines for terrestrial animals, 2018 Paris: OIE; 2018. Ovine epididymitis (Brucella ovis). http://www.oie.int/fileadmin/Home/eng/Health_standards/tahm/2.07.08_OVINE_EPID.pdf (Accessed 11 Mar 2018)

Primljeno: 06.12.2018.

Odobreno: 26.12.2018. 